\title{
Roma seminomadic tradition between social inclusion and the protection of natural
} resources: a Case study of the Toplica District (Serbia)

Aleksandar Valjarević ${ }^{1,21}$, Jasmina Petrović ${ }^{3}$ Olivera Marković-Savić ${ }^{4}$ Dejan Filipović ${ }^{5}$ Dušan Ristić $^{6}$, Dragan Radovanović ${ }^{6}$

${ }^{1}$ Deparment for Management of Science and Technology Development, Ton Duc Thang University, Ho Chi Minh City, Vietnam,

${ }^{2}$ Faculty of Environment and Labour Safety, Ton Duc Thang University, Ho Chi Minh City, Vietnam

${ }^{3}$ Faculty of Philosophy, University of Niš, Ćirila i Metodija 2, 18000 Nišs, Serbia; jasmina.petrovic@filfak.ni.ac.rs

${ }^{4}$ Univeristy of Kosovska Mitrovica, Faculty of Philosophy, Department of Sociology, Filipa Višnjića b.b, 38220 Kosovska Mitrovica, Serbia; markovic.olivera@gmail.com ${ }^{5}$ Univeristy of Belgrade, Faculty of Geography, Studenstskitrg 3/III, 11000 Belgrade, Serbia prof.dejanf@gmail.com

${ }^{6}$ University of Priština-Kosovska Mitrovica, Faculty of Sciences, Department of Geography, Ive Lole Ribara 29, 38220 Kosovska Mitrovica, Serbia, dusan.ristic@ @r.ac.rs; dragan.radovanovic@pr.ac.rs

\section{Abstract}

Using the existing knowledge about the social and cultural characteristics of the Roma in Serbia, acquired in a number of social and other related studies, as well as the data obtained through the GIS methodology for determining the spatial distribution of Roma settlements and activities of the Roma community within the Toplica District (one of the districts in Serbia with a high percentage of Roma population) and their daily migrations which are realized within a geographical space, the paper investigates the possibility to raise the level of their economic activity and social integration, while simultaneously preserving natural resources and improving environmental safety. This issue takes on additional meaning in a situation where Serbia is simultaneously faced with the problem of raising standards in the areas of environmental protection and social inclusion of the Roma ethnic community that survives on the margins of society with all the characteristics of socially deprived groups.

Keywords: Roma, Toplica District, social inclusion, protection of natural resources

\footnotetext{
${ }^{1}$ Corresponding author: Aleksandar Valjarević aleksandar.valjarevic@tdtu.edu.vn
} 
Introduction

Although the Republic of Serbia covers a relatively small area of $88804 \mathrm{~km}^{2}$, it has a large number of Roma settlements. A field study ${ }^{2}$ conducted in the first decade of the current century "recorded that in Serbia there are 593 Roma settlements with more than 15 families, with more than 100 Roma people" (Bašić, Jakšić, 2006: 37). The presence of the Roma population is also significant in the territory of the Toplica District that has an area of 2231 $\mathrm{km}^{2}$. The Toplica District is located in the south-eastern part of Serbia, bordering with the Raška, Nišava and Rasina Districts, and partly with Kosovo. The total population according to the census of 2011 (Republic Statistical Office; X volume) amounted to 91,754 with an average density of 41.1 per $\mathrm{km}^{2}$. The depression of Toplica is located between mountains Jastrebac, on the north, and Pasjača, Vidojevica, Sokolovica and partly Radan on the south, with an average height of 400 to 500 m (Maćejka \& Tanasković, 2008: 23-9). The river after which the district was named flows through the central part of the depression dividing it into two parts (the Upper and Lower Toplica). The Toplica river, $130 \mathrm{~km}$ long, flows into the

${ }^{2}$ Conducted within the project Roma settlements, living conditions and possibilities of integration of the Roma in Serbia: with the aim of taking effective measures to improve living conditions and investigate the possibility of integration, with the financial support of OXfam, GB, Belgrade office. 
South Morava and connects to the South Morava river basin. The Toplica District was settled in antiquity. Some ethnic groups that inhabited this area were: the Avars, the Celts, the Dardanelles, the Turks, the Slavs, while the Roma as a community are mentioned in Turkish records from the fifteenth century. After the Battle of Kosovo in 1389, the Turks conquered Toplica, so the ethnic structure was changed. The first written accounts of Roma settlements were given by a Turkish travel chronicler (Evliya Çelebi) in the seventeenth century, although it cannot be determined with certainty whether he separated the Roma population from the Serbs. An Austro-Hungarian researcher, historian and a travel chronicler (Kanitz, 1868: 356-61) described the Roma population in the Toplica District living on the outskirts of towns of Kuršumlija and Prokuplje, where it is mainly located today (Kanitz,1868). According to the last census from 2011, the number of Roma people has increased, both in Serbia as a whole, and in the district.

Socio-demographic analyses suggest that this increase cannot be attributed solely to the processes related to natural and mechanical demographic factors, such as, for example, an increase in the birth rate, the reduction of mortality or the migrations (Raduški, 2014:206-7). In the first census after the Second World War in 1948, $0.8 \%$ of the total population of Serbia declared themselves as members of the Roma ethnic group, and that level was maintained up to the census in 1961 , when it declined to only $0.1 \%$. A decade later, during a wave of ethnic emancipation which affected Serbia, the Roma declared ethnicity more freely $(0.7 \%)$, and this practice has been particularly intense since the nineties of XX century. Thus, the proportion of the Roma in the population of Serbia in 1991 was $1.4 \%$, reaching $2.1 \%$ in 2011, so the Roma became the third largest ethnic group in Serbia (after the Serbs and the Hungarians). A series of political, legal and socio-cultural factors contributed to a freer expression of ethnicity and the repression of expressed ethnic mimicry. They need to be identified not only in the fact that, with the disintegration of Yugoslavia, a supranational framework for identification 
disappeared but also in factors such as intense efforts of Roma activists to preserve the ethnic identity of the Roma in Serbia and, in the wider international level, to raise awareness about the importance of accepting their own national identity, together with a number of social policy measures that promote the full social inclusion of the Roma population in Serbia. However, ever present explicit and latent discriminatory practices, although formally and legally impermissible, contribute that a part of the Roma population in Serbia conceal their ethnic identity. This applies in particular to the population that does not live in spatially segregated settlements and that has achieved a certain degree of social integration. According to scientific estimates, there were at least twice as many Roma in Serbia at the beginning of XXI century than the census results showed (Bašić and Jakšić, 2006:43). The Toplica District, particularly the municipality of Kuršumlija, has very large afforested areas, except Žitoradja (Kuršumlija 63\%, Prokuplje 39\%, Žitoradja 12\%, Blace 37\%). Due to a negative birth rate, in the municipality of Prokuplje forests have been returning to their former habitats (Valjarević et al., 2014; Valjarević et al., 2018). At first glance, this scenario has positive effects on the environment and natural capacity of the District. However, the biggest problem faced by Serbia in joining the European Union is precisely the deficiency in the area of environmental protection. The Roma settlements are largely situated on the fringes of forests, or even inside the forest belts, so with the rise of environmental awareness, the Roma population could become an active factor in the preservation of the forest belts. This is especially true if one takes into account that, when it comes to joining the EU, Serbia is particularly lagging behind in opening the chapters dealing with ecology and environmental protection (Stopić et al., 2009), (See also, Figure 1.). 


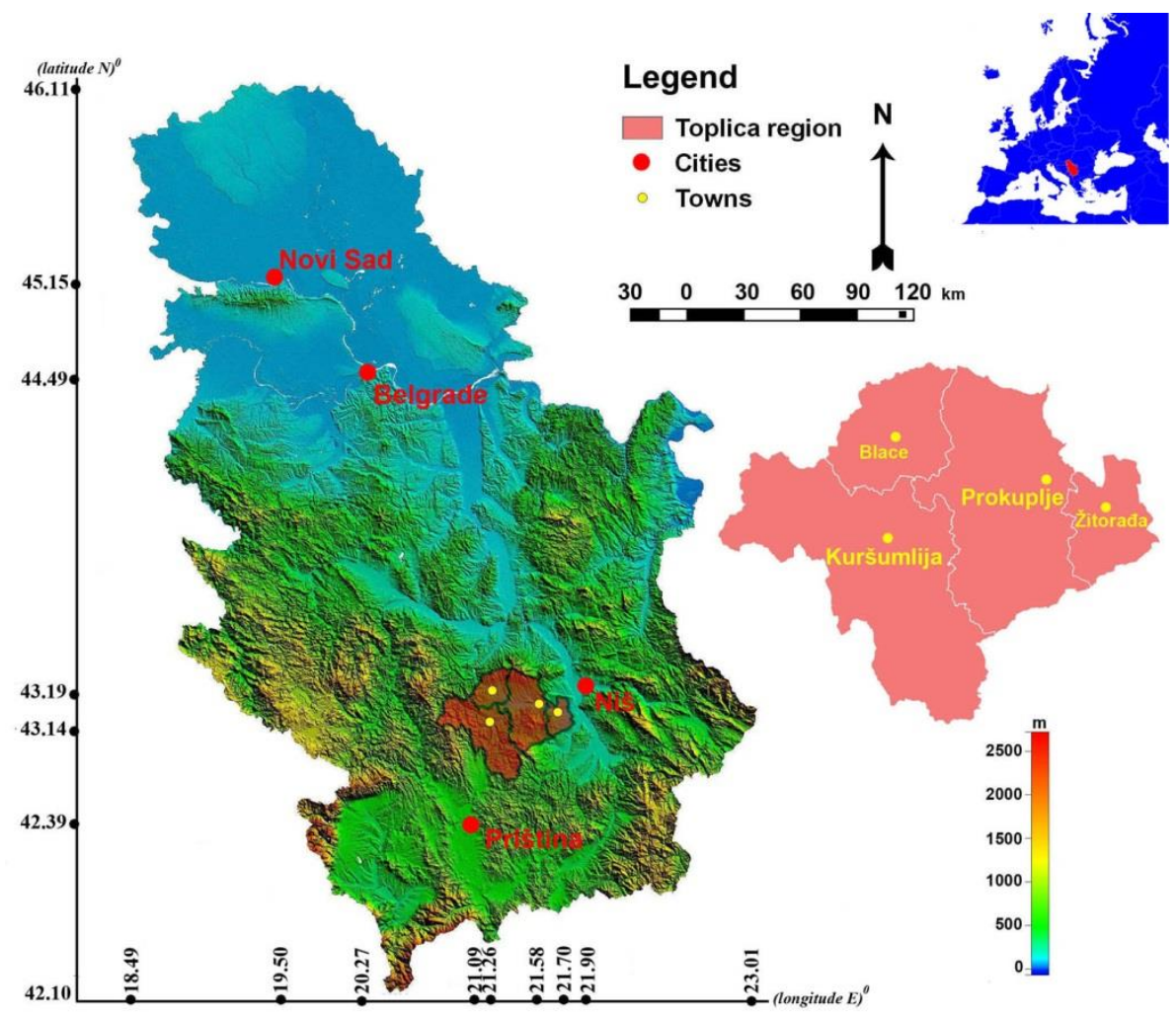

Fig. 1. The position of Serbia and the Toplica District

Cultural and social practices of the Roma community in Serbia

As part of the cultural tradition of the largest Pan-European minority, Roma cultures in Serbia

have some universal elements resulting from the intermingling of a series of broader historical, economic and political factors including the influence that originated from the intercultural exchange. The attitude that the Roma outlook on the world is "based on archaic images that they brought from their homeland" is not without foundation (Djurović, 1996: 89). However, cultural identity and cultural practices of the Roma in Serbia cannot be understood apart from the micro and macro socio-cultural milieu in which the Roma communities survive. The Roma, as a social group, are characterized by the cultural, social, religious and residential diversity (Djordjević, Todorović, Djordjević, 2000; Sokolovska,

117 2014; Škorić, Kišjuhas, 2014), as well as social mimicry and a relative group closure that is not only reactive in type - a response to social isolation, but also a form of "protection of 
group identification and a way of preserving the group order and structure" (Sokolovska, 2014: 8).

\section{Cultural and social practices of the Roma community in Serbia}

As part of the cultural tradition of the largest Pan-European minority ${ }^{3}$, Roma cultures in Serbia have some universal elements resulting from the intermingling of a series of broader historical, economic and political factors including the influence that originated from the intercultural exchange. The attitude that the Roma outlook on the world is "based on archaic images that they brought from their homeland" is not without foundation (Djurović, 1996: 89). However, cultural identity and cultural practices of the Roma in Serbia cannot be understood apart from the micro and macro socio-cultural milieu in which the Roma communities survive. The Roma, as a social group, are characterized by the cultural, social, religious and residential diversity (Djordjević, Todorović, Djordjević, 2000; Sokolovska, 2014; Škorić, Kišjuhas, 2014), as well as social mimicry and a relative group closure that is not only reactive in type - a response to social isolation, but also a form of "protection of group identification and a way of preserving the group order and structure" (Sokolovska, 2014: 8). For several decades, the key characteristics of their social status have been: a) spatial segregation - a common practice of living in separate (ethnically cleansed) settlements that in appearance reflect the state of permanent misery of the majority of Roma population that is dramatically manifested in the organization and way of life "(Bašić and Jakšić, 2006: 36); b) an extremely unfavorable education structure and a high proportion of illiterate population in comparison to the same parameters of other ethnic groups in Serbia (MHMRSM, 2004); c) frequent unemployment or engagement in least paid and stigmatizing positions; d) a low level of inclusion in health and social care; e) the lack of political participation, public action and international organization (Mitrović, 1996:815; Todorović, 2011: 1139); f) low social capital - social relations of the Roma population in Serbia are

\footnotetext{
${ }^{3}$ Some residents of the Toplica District came before Slavs migrations to the Balkan Peninsula.
} 
primarily based on contacts, the exchange of information and support within the immediate and extended kinship community, all of which makes social inclusion difficult (Škorić and and social practices in which the majority of the members of the Roma ethnic group live are the reasons that the Roma in Serbia lack the resources important for the preservation of ethnic and cultural identity ${ }^{5}$, as well as the resources for true social integration that does not mean assimilation and suppression of their cultural and ethnic identity. Observed from the standpoint of the theme of this paper, the professional practices of the Roma in Serbia are of great importance, namely the ways in which this ethnic group earns an existence. In this regard, it is important to present the results of a research carried out in 2014 as part of the a stratified sample (based on the results of the census conducted in 2011 in the Republic of

\footnotetext{
${ }^{4}$ At the same time, the stereotypical images are saturated with negative qualities attributed to the Roma as being dirty, lazy, primitive, prone to theft and so on. This stable core of stereotypes is home to several positives ones that occur as a constant in most studies of ethnic stereotypes - for example, happy, musical (Turjačanin, 2004; Petrović, Šuvaković, 2016).

${ }^{5}$ True, it should be said that the social situation of the Roma in most countries of the so-called Western Balkans does not differ greatly from their position in Serbia.

${ }^{6}$ The research was conducted through the cooperation of the Department of Sociology, University of Novi Sad, the Department of Sociology, Faculty of Philosophy in Nis and the Department of Sociology, University of Belgrade. Also, the research was joined by a leading researcher of the Roma population in Serbia prof. Dr Dragoljub Djordjević, and the representatives of the Roma community and great connoisseurs of Roma culture Osman Balić, Zoran Tairović and others were consulted.

${ }^{7}$ Out of the total population that ethnically identified themselves as members of the Roma ethnic group, $29 \%$ live in Vojvodina, $18 \%$ in the Belgrade region, $14 \%$ in the region of Šumadija and Western Serbia, and 39\% in the region of Eastern and Southern Serbia.
} 
accounted for $0.82 \%$ of the total Roma population in Serbia. The survey was conducted in 34 municipalities which, according to the results of the 2011 census, recorded a high share of Roma people in the total population. In order to encompass the diversity of the Roma population in the research, in the formation of the sample a special attention was placed on the residential aspect that is directly linked to the degree of integration of the Roma into mainstream society, that is, the autochtony of Roma communities and cultural practices. For these reasons, a more detailed classification of the areas where Roma people live was created. The city and village areas where the research was conducted were divided into urban/rural microregions (where there is no territorial concentration of the Roma, but they are integrated into the rest of the population), Roma settlements (mahalas) in cities/villages, slums in cities/villages, mahalas and slums outside of the cities/villages and the suburban settlements ${ }^{8}$. The gender structure follows the structure of the population recorded in the census. Data from our study largely remain within the estimate presented in the Report on the situation of minorities in Central Serbia, compiled in 2000, according to which in Central Serbia only 5\% of the Roma work in publicly owned enterprises, and there are practically no Roma in the executive government (Brza, 2000: 23). Although there is improvement compared to the period of a decade and a half ago, it is not large. Thus, less than a third of respondents in the sample classified themselves into one of the offered activity sectors. Only $5.4 \%$ said that by profession they belonged to the sector of economic production, $3.1 \%$ to agriculture, $5 \%$ to trade, catering and tourism, and the same number to the service sector. The Public Services (administration) employ only $4 \%$ of the respondents, healthcare and education $5.4 \%$, and the culture and information sector $1.4 \%$. The results that we got show that the structure of specific occupations among the Roma in Serbia is dominated by the unpaid work of housewives with

\footnotetext{
8 In the city microregion, $11 \%$ of respondents were questioned, in a city mahala $38.2 \%$, in a city slum $4.7 \%$, in Roma settlements by the city $8.4 \%$, in a slum by the city $3.3 \%$, in a suburb $6,8 \%$, in a village $16.9 \%$, in a Roma settlement in a village $9 \%$, in a village slum $0.2 \%$, in a Roma settlement by the village $1.1 \%$, in a slum by the village $0.4 \%$.
} 
$29.4 \%$, mainly carried out by women. Then, there is wage labor (mainly doing simple and hard labor without a regulated employment status) with $20 \%$, the collection of recyclable materials $13 \%$, resale of goods, either through legal or illegal forms of trade $10.8 \%$. Only $6.6 \%$ of the questioned Roma stated they were employed in an economic unit as a worker. Craft products and services employ $5.1 \%$ of the Roma, playing music 3.8\%, street cleaning $3.1 \%$, while only $2.4 \%$ perform agricultural activities. Among the Roma, there are few who hold jobs for highly-qualified persons: $0.2 \%$ are lawyers, $0.9 \%$ are pedagogues, $0.3 \%$ are teachers, $0.3 \%$ are engineers. There are very few among administration officers, $1.2 \%$, and $0.9 \%$ among the taxi drivers, or medical and paramedical personnel, $0.9 \%$. Sporadically, they engage in begging, $0.4 \%$, divination and healing, $0.3 \%$. Traditional past occupations of Roma people on the territory of Serbia ${ }^{9}$ are present in $63.9 \%$ of respondents' families. Playing music is dominant with $24.1 \%$, peonage with $21 \%$, blacksmithing $8.3 \%$, reselling horses and carpentry each with $1.7 \%$. Other traditional jobs (such as goldsmiths, weaving, processing of feathers and the like) are present in the families of respondents with less than $1 \%$. A consideration of the intergenerational transfer of interest provides an interesting picture. When we compare the occupations of the respondents and the occupations of their fathers, it can be seen that the occupations of fathers and offspring do not overlap entirely, because many of the fathers' jobs are not even mentioned as activities that respondents currently perform (seed seller, a rope maker, an umbrella repairman, a blacksmith, a knife sharpener, etc.). However, some occupations appear as traditional family occupations that are performed by fathers and sons/daughters. Thus, $65.9 \%$ of those who said they were playing music listed a musician as the father's profession, $42.9 \%$ of laborers said that their father had also performed the same job. Slightly more than a quarter of respondents $(25.6 \%)$ who work in the collection and sale of secondary raw materials stated the identical occupation of their fathers.

\footnotetext{
${ }^{9}$ More about this in Djordjević, 1984, Volume III; Todorović, 2000, 313 - 333.
} 
So, despite the fact that some jobs disappeared, and that today in Serbia much less Roma are employed as workers in the economy, there remains a number of occupations that is transferred through generations among the Roma. Taking into account the low social status of this minority group (the lack of education, the lack of economic inclusion, consequently, the lack of material resources, access to the media, bank loans and other social resources), the question about the possibility of their social integration into mainstream society is being raised (Postma, 1996). For, the vicious circle of social exclusion is being repeated: the exclusion from education reduces the chances on the labor market (Sparkes, 1999, Petrović, 2011), and the exclusion from the labor market reduces the availability of social benefits that act as insurance in case of illness, old age, inability to work, whereby the higher the risk of long-term exclusion or the exclusion in later years of life (Babović; Cvejić;Pudar, 2010). The chain continues with the material, cultural and political deprivation, which reduces the chances for the establishment of social relations outside their deprived groups and produce a feeling of powerlessness, personal and social incompetence, passiveness (Sen, 2000). In the case of the Roma in Serbia, the situation is more than clear, particularly when one takes into account the structure of their economic activity. ${ }^{10}$ Equipped with such information on the Roma population in Serbia as a whole, we asked whether the spatial distribution of the Roma population in the area tested and their registered daily migrations within the geographical space with the aforementioned natural characteristics can become a part of the policy of social inclusion of the Roma population in the wider community. We believe that such potential exists.

Natural resources of the geographical space in the function of the social inclusion of the

\section{Roma community}

\footnotetext{
${ }^{10}$ According to the results of the 2011 census, only $11.45 \%$ of the Roma population are economically active, $16.50 \%$ are unemployed, $4.4 \%$ are pensioners, $0.10 \%$ have property income, $35.15 \%$ are children, pupils and students, $17.28 \%$ are housewives, while $15.12 \%$ belong to the category of others (persons with other personal income, as well as persons unable to work or other persons who do not belong to the above categories.
} 
Ecological geography experiences development by asking the question whether humanity is viable even when separated from nature. The largest development of ecological geography happened in the eighties of the last century when the first conference on the effects of global warming had a panel discussion on how we can save the planet Earth and whether the development in perpetual motion is sustainable or not. Eurocentric dualism failed to separate the influence of politics on society, even if the society was far from modern, or not sufficiently accepted by the major communities (Hobson, 2007). The theory on super-natural effects in geography failed to absolutely come to life. So, today, there is insufficient evidence that nature is inherently sustainable. Theoretical ecological geography together with political geography calls for the possibility of post-humanism as a direction that will, due to the great development and therefore the technology, be able to solve some of the most pressing problems of mankind, including certain minority communities in certain territories that have their own characteristics in the ontological sense (Sundberg, 2014). Ecological Geography is not only important for the acquisition and protection of certain resources within nature, but also because the development of environmental awareness can prevent conflicts and strengthen efforts to protect nature (Berdal and Keen, 1997; Le Billon, 2000; Barnett, 2001). In other words, it is necessary to ensure environmental security and efforts to preserve local and planetary biosphere as a fundamental system underpinning all human activities. A geographical space itself can sometimes present certain communities that are traditionally close to it. The Roma community is related in part to the semi-nomadic way of life, although its concept and way of life has changed due to globalization, new technology, and improved social conditions of existence. To that extent, the nomadic way of life has been increasingly replaced by a sedentary life, so migration and nomadic life usually occur as a result of discrimination in different historical periods in different geographic areas (Barany 1994; Škorić and Kišjuhas, 2014). Anthropological semi-nomads within the Toplica District are 
bound to three coordinates within the geographic space (Barlovo-Kuršumlija, a suburb of Prokuplje, Staklara settlement and Kastrat Municipality in Kuršumlija).

\section{Materials and Methods}

GIS and data modelling is a very powerful tool for calculating and describing certain population properties in a specific area. In this paper, we analyzed demographic characteristics and the changes of Roma population in the Toplica District. For that purpose, we used GIS software QGIS, Grass GIS and SAGA, with tools for geospatial calculations. (Bíl et al., 2012). The satellite recordings of the land and forest areas were downloaded from the official web page of CORINE (Coordination of Information on the Environment), while from the official web page (http://www.eea.europa.eu/publications/COR0-landcover) we downloaded vector data with the exceptional view of coniferous, broad leaved and mixed forests, (Wu and Chen, 2016; Frechtling, 1999). After downloading the data, we exported it to the GIS software. In GIS we cropped the territory of the Toplica District for future manipulation of vectorized data. In QGIS, we georeferenced raster data and digitized all positions of Roma settlements. The Ordinary Kriging method is a fundamental part of tools implemented in software Quantum GIS and SAGA (GIS) dealing with spatial analysis. Although there are a few other methods, the priority was given to Ordinary Kriging and the Global Kriging method because of the most realistic autocorrelation and the statistical relationship among the measured points. Thus, with this method, the weights are based not only on the distance between the measured points and the prediction of location, but also on the overall spatial arrangement of the measured points, and it minimizes the variance of the error of estimation. The Ordinary Kriging method was employed through QGIS and SAGA (GIS) extension of Spatial Analyst. The map of the Roma settlements and Roma daily migrations (given in Table 1) in the territory of the Kuršumlija municipality was made using this method (Fig.2,3).

\section{Results and Discussion}


Empirical research points to the widespread social exclusion of long-established Roma communities in their home countries, one of which is Serbia (Guy, 2001; Prieto-Flores, 2006; Sigona, 2005). The results of the census in 2002 show a very small number of Roma people in the Toplica District. After the war in Yugoslavia (1991-1999), Roma people declared themselves as being Serbs (Ljujić et al., 2012). The official data of the census in 2002 show that, in the Republic of Serbia in the entire territory of the Toplica District, the number of Roma population was 3338 or $3.27 \%$. Data from the last census in 2011 show that the number of Roma people significantly increased to 4278 or $4.72 \%$, while the total population decreased. The data show that the number of Roma people has not increased in demographic terms, but that the process of segregation has been reduced due to the activities of the institutions of the European Union. We calculated the migration of the Roma population using numerical and statistical methods. Also, we used the data from the terrain analyses in Roma settlements. Other methods we used are: interviews, oral questions, written questions, statistical books, census materials, etc. With the help of GIS and numerical analysis, we divided the belts of the Roma population and their gravitational influence in relation to forests, and the opposite impact of forests to the areas where the Roma live. The strongest influence of $85-100 \%$ around three towns and two villages covers an area of $44 \mathrm{~km}^{2}$ in Kuršumlija, $52 \mathrm{~km}^{2}$ in Ž.Potok, $229 \mathrm{~km}^{2}$ in Prokuplje, $157 \mathrm{~km}^{2}$ in Žitoradja. The very strong influence between $65-85 \%$ is in Kuršumlija with a covered area of $14 \mathrm{~km}^{2}$, Ž. Potok with 19 $\mathrm{km}^{2}$, Prokuplje with $34 \mathrm{~km}^{2}$ and Žitoradja with $17 \mathrm{~km}^{2}$. The medium influence of $45-65 \%$ belongs to the area of $12 \mathrm{~km}^{2}$ in Kuršumlija, $14 \mathrm{~km}^{2}$ in Ž.Potok, $19 \mathrm{~km}^{2}$ in Prokuplje, $18 \mathrm{~km}^{2}$ in Žitoradja. The light influence of $25-45 \%$ is present in an area of $16 \mathrm{~km}^{2}$ in Kuršumlija, 18 $\mathrm{km}^{2}$ in Ž.Potok, $20 \mathrm{~km}^{2}$ in Prokuplje, $11 \mathrm{~km}^{2}$ in Žitoradja. The very light influence of 5-25\% covers an area of $20 \mathrm{~km}^{2}$ in Kuršumlija, $12 \mathrm{~km}^{2}$ in Ž.Potok, $30 \mathrm{~km}^{2}$ in Prokuplje, $10 \mathrm{~km}^{2}$ in Žitoradja. No influence or a slight influence of $0-5 \%$ belongs to the rest of the territory in 
Kuršumlija of $846 \mathrm{~km}^{2}$, Ž.Potok doesn't have the influence area of 0-5\% because Ž. Potok covers an area of $13.4 \mathrm{~km}^{2}$ and the influence is higher than the whole territory. Prokuplje covers area of 0-5\% influence with $427 \mathrm{~km}^{2}$ and Žitoradja does not have the influence area of $0-5 \%$ (see Figure 2). Therefore, the area covered in forest is not the same because forests don't cover a similar area, for example, in municipalities of Prokuplje and Žitoradja, there is a different dispersion of forest. According to satellite recordings, we measured the forest areas in the municipalities. In 2015 in the municipality of Prokuplje, forests cover the total area of $40.5 \%$, in Žitoradja $12.8 \%$, in Blace $38.2 \%$ and in Kuršumlija $64.5 \%$. In comparison to the last census data from 2011, the municipality of Prokuplje has an increment of 1.5\%, Žitoradja of $0.8 \%$, Blace of $1.2 \%$ and Kuršumlija of $1.5 \%$. Since we divided forests into three categories (broad-leaved, coniferous and mixed), the coniferous forests are especially threatened since their territory has been decreasing for many years. Conifers that are strongly influenced by potential cuts spread over an area of $0.32 \mathrm{~km}^{2}$. In the municipality of Prokuplje, this area is $1.9 \mathrm{~km}^{2}$, on the territory of the Municipality of Žitorađa it is $0.4 \mathrm{~km}^{2}$, in the municipality of Blace there are no coniferous forests and a consequent influence. The pressure on mixed forests would cover the following surfaces; $0.8 \mathrm{~km}^{2}$ in the municipality of Žitorađa, $0.4 \mathrm{~km}^{2}$ in the municipality of Kuršumlija. Other municipalities do not have a potential pressure on mixed forests. The pressure on broad-leaved forests which are most frequent in the territory of the Toplica District has the following values: in the municipality of Kuršumlija this area is $30.2 \mathrm{~km}^{2}$, in the municipality of Prokuplje the area is $183.5 \mathrm{~km}^{2}$, while in the municipality Žitorađa it is $36.3 \mathrm{~km}^{2}$. The increase in the total amount of forestation can clearly be explained by the fact that forests have been returning to their initial habitats (Valjarević et al., 2014). Based on the obtained results covering a long period, it can be concluded that the forestation increased greatly, which indicates a decreased number of settlements (according to the Census of the Republic of Serbia from 2011, numerous villages 


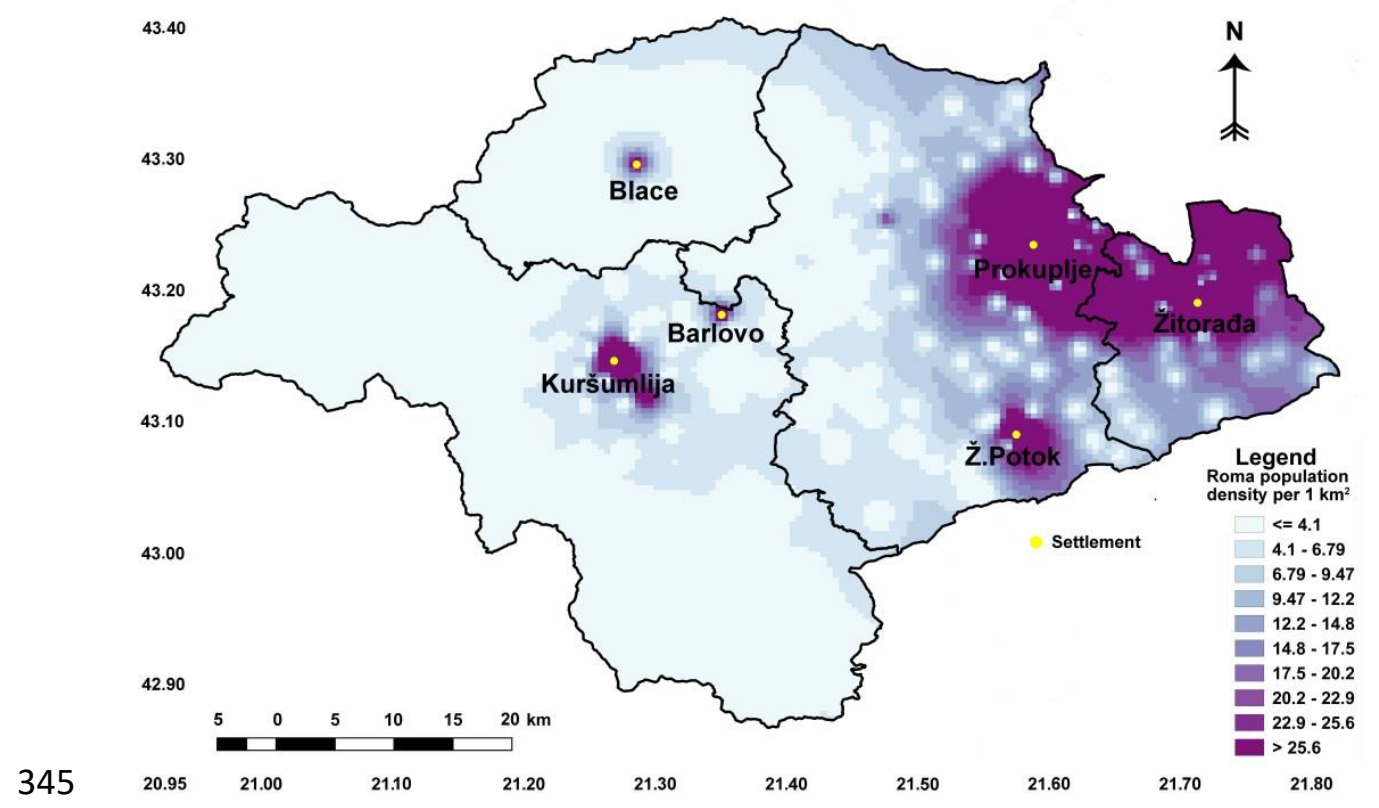

were abandoned) due to social changes in the Toplica District during the period from 1984 to 2012. Monitoring the Toplica District has shown the tendency of increased urbanization related solely to the central parts of the towns, which indicates the constant rural to urban of the population from this area is noticed, especially to Belgrade, the capital of Serbia (according to the Census of the Republic of Serbia from 2011, the depopulation of this territory amounted to $8.1 \%$ ). The Roma population moved to the central part of the region especially to the city of Prokuplje, because many of them were not included in the reform conditions on the suburb zones of the towns of Prokupje and Kuršumlija (see Figure 4). migrations. Namely, due to social changes in the Toplica District during the period from 1984 to 2012, the level of industrialization considerably decreased. Therefore, a constant migration process and resocialization (Rudić, 1978; Janević et al.,2010). Many of them live in inhumane

Fig. 2. The map of Roma population density in the Toplica District according to the data from the census of 2011 


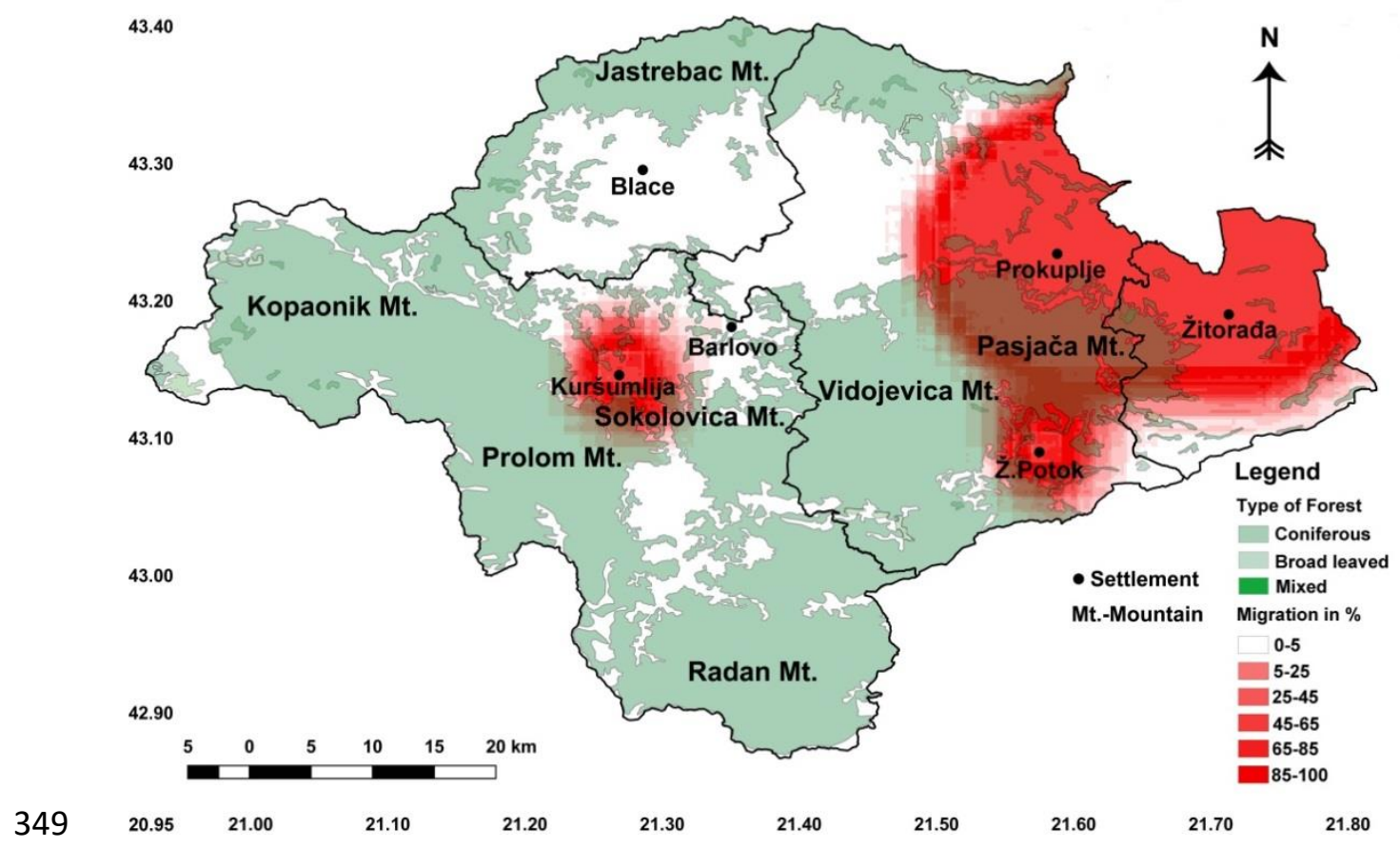

350 Fig. 3. Migration of Roma population to forest areas per one year in \%, data from the terrain 351 analysis and from the local books of the municipality of Prokuplje

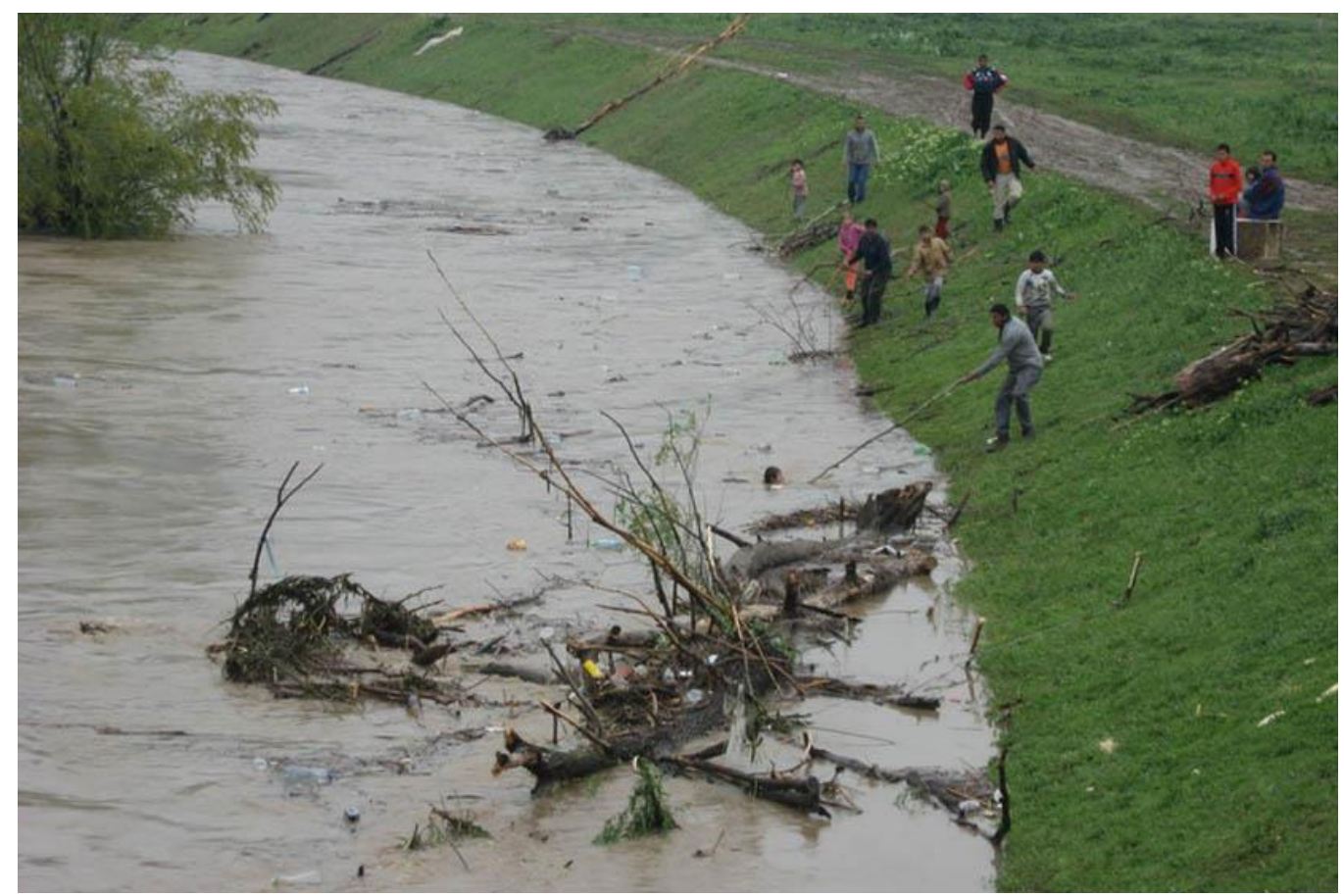

353 Fig. 4. Roma community in the flow in the edge of the subway of the city of Prokuplje

\section{Conclusion}

355 Identified determinants of the studied geographical territory (primarily pronounced forestation and the return of forest resources to previous habitats) and the potential impact of population 
on forest resources that was found require the consideration of measures to preserve and protect these natural resources, particularly given the weaknesses of the system of ecological safety in Serbia. On the other hand, a significant concentration of the Roma population in the study area that is recorded, and the characteristics of their social status, including spatial and overall social segregation, offer the possibility to include this population in the protection of ecosystems through certain systematic measures. By initiating a wide range of activities to preserve local ecosystems, especially forest resources, the Roma ethnic community could become one of the key actors. As a population with a very low rate of economic activity, it could be trained to recognize the potential for self-employment (in the business of preserving forest resources, reforestation, forest cleaning and the collection of recyclable materials improperly deposited on the forest ground, and in many other activities). Resources, as valuable goods in society (Granovetter, 1973), whose maintenance and improvement Roma communities may deal with, can become the basis for strengthening their economic and overall social position, especially if one takes into account the experience of their members in the area of forestry. At the beginning of the current century, among the economically active members of the Roma ethnic community, it was found that as many as $23 \%$ of them were engaged in agriculture, hunting and forestry (MHMRSM 2004:445).Researchers do not perceive such activities as a new form of social exclusion of the Roma, removing them from the main currents of social life in Serbia. On the contrary, we see their role in connecting current major environmental issues which Serbia has to address in the future, which means the standardization of this activity in the process of joining the EU, and the issues of social integration of the Roma ethnic minority. This issue takes additional significance when we take into account the low economic potential of the area and the deindustrialization of the entire region lasting several decades, which substantially reduces the chances of getting a job, wherein the possibilities of the Roma community are even fewer, in view of its extremely 
adverse educational structure. ${ }^{11}$ Namely, more than half of the Roma community in Serbia have no education or have incomplete elementary education $(53.72 \%)$, a third have completed the elementary education $(33.3 \%), 11.54 \%$ have completed secondary education, while only 0,65\% have university education (Sokolovska, Jarić, 2014, p. 386), wherein this structure is even more unfavorable in underdeveloped areas of Serbia such as the Toplica District. For these reasons, the spatial and social segregation of the Roma in the Toplica District could be turned into its opposite. The knowledge of the terrain, the migratory practices and a spatial proximity to significant natural resources, paired with appropriate education for environmental protection and occupational training to perform certain tasks within the forest areas in the Toplica District could give the Roma a significant opportunity for a way out of the vicious cycle of poverty and social deprivation, not only by providing new sources of existence, but also by strengthening their social ties with the local population. All this together could become an example of good practice in the social integration of the Roma.In doing so, it is of course necessary to further efforts and implement other measures for social inclusion, such as an intensive commitment to include all Roma children of age in all levels of formal education in Serbia, as well as other activities on strengthening their social and cultural potential.

\section{Acknowledgment}

The authors are very grateful to the Ministry of Labor and Office for Human and Minority Rights for providing data, as well as to the Roma Office of the Republic of Serbia.

\section{References}

Barnett, J., (2001). The Meaning of Environmental Security: Ecological Politics and Policy in the New Security ERA, London and New York: Zed Books.

\footnotetext{
${ }^{11}$ According to the latest census, in the Republic of Serbia, $13.68 \%$ of the population has no formal education, or has only incomplete primary education, where the Roma ethnic community accounts for almost half of the population in this category $-6.38 \%$ (SORS, 2014).
} 
Berdal, M., Keen, D., (1997). Violence and economic agendas in civil wars: some policy implications. Millenium: Journal of International Studies, 26: 795-818.

Briza, J., (2000). Minorities in Central Serbia, Minorities Right in Yugoslavia, London: International Report, No. 6, Minority Rights Group.

Bíl, M., Bílová, M., \& Kubeček, J., (2012). Unified GIS database on cycle tourism infrastructure. Tourism Management, 33 (6):1554-1561. http://dx.doi.org/10.1016/j.tourman. 2012.03.002.

Djordjević, D., (2010). On horseback with a laptop in the saddlebag - an introduction to the Romany studies. Niš: Faculty of Mechanical Engineering.

Djurović, B., (1996). Social segregation and ghettoized consciousness of the Roma, Gypsies/Roma in the past and today. Proceedings of the conference held on December 16 and 17, 1996, 89-96. Belgrade: SASA.

Djordjević, D., Todorović, D., (1999). Maple overhead - classical religion and RomaOrthodox village cemeteries. Niš: Komren Sociological Meetings, Good Action Society.

Guy, W.(Ed.). (2001). Between pastandfuture:The Roma of Central and Eastern Europe. Hatfield: University of Hertfordshire Press.

Hobson, K., (2007). Political animals? On animals as subjects in an enlarged political geography. Political Geography, 26 (3): 250-267. doi:

http://dx.doi.org/10.1016/j.polgeo.2006.10.010.

Janjesevic, T., Petrovic, O., Bjelic I., Kbera A., (2010). Risk factors for childhood malnutrition in Roma settlements in Serbia. BMC Public Health, 10:509, doi: 10.1186/14712458-10-509.

Jakšić, B., Bašić, G. (2005). The art of survival. Where and how the Roma live in Serbia. Belgrade: Institute for Philosophy and Social Theory. 
Janjesevic, T., Petrovic, O., Bjelic I., Kbera A., (2010). Risk factors for childhood malnutrition in Roma settlements in Serbia. BMC Public Health, 10:509, doi: 10.1186/14712458-10-509.

Kanitz P Felix, “Serbien - historisch-ethnographische Reisestudien”, (Leipzig, Special Collection, 1868).

Keen, D., (1998). The economic functions of violence in civil wars. Oxford: Oxford University Press.

Lazar, Ž., Koković, D., (2005). Ethnical distance in Vojvodina - research results. The Sociological Review, 39: 251-264.

Le Billon, P., (2000b). The political economy of war: an annotated bibliography. HPG Report 1. London: Overseas Development Institute. (Website: http://www.odi.org.uk/hpg/warecons). Ljujic, V.,Vedder, P., Dekker, H., Van Geel, M., (2012). Serbian adolescents’ Romaphobia and their acculturation orientations towards the Roma minority, 36 (1): 53-61. doi: http://dx.doi.org.proxy.kobson.nb.rs:2048/10.1016/j.ijintrel.2010.11.015.

Miladinović, S., (2008). Ethnic and social distance towards the Roma. The Sociological Review, 42, 417-437.

Mitrović, A., (1990). At the bottom: the Roma at risk of poverty. Belgrade: Scientific Book. Mitrović, A., (1996) The position of the Roma in society - a possible approach to the study of the Roma population. The position of minorities in the Federal Republic of Yugoslavia, Macura Miloš, Vojislav Stanovčić [ed.], 807-818 Belgrade: SASA.

Mitrović, A., Zajić, G., (1988). The social position of the Roma in Serbia. The Roma in Serbia, 9-64. Belgrade: Center for Anti-War Action and the Institute for Criminological and Sociological Research. 
Mitrović, A., (1996). The position of the Roma in society - a possible approach to the research of the Roma population. In: M. Macura and V. Stanovčić (ed). The position of minorities in the Federal Republic of Yugoslavia, 807-818, Belgrade: SASA.

MHMRSM [Ministry for Human and Minority Rights of Serbia and Montenegro] (2004) Ethnic Mosaic of Serbia. Belgrade: Ministry of Human and Minority Rights of Serbia and Montenegro.

Petrović, J., (2014). Between traditional heritage and aspirations towards modern forms of life: marriage, family and family relations of the Roma in Serbia. In The social and cultural potentials of the Roma in Serbia, V. Sokolovska (prep.), 29-53. Novi Sad: Faculty of Philosophy, Department of Sociology, Center for Sociological Research.

Petrovic, J., Suvakovic, U., (2013). "We" and "others" - Stereotype attitudes of Serbian student youth. Vestnik RUDN, Sociology Series ,4: 52-65.

Petrović, J. (2011). Literacy level and the educational structure of the population living in the border municipalities in Eastern and Southeastern Serbia: A potential for development or a factor of social exclusion? Teme XXXV, 4:1495-1520.

Petrović, J., Šuvaković, U., (2016). The social distance of Serbian, Macedonian and Bulgarian students in relation to the Roma. Yearbook of Sociology XI (14-15):7-22.

Postma, K., (1996). Changing negative attitudes in Hungary: A study on the collapse of state socialism and its impact on negative attitudes against Gypsies and Jews, PhD thesis

Groningen University, the Netherlands.

Prieto Flores,O., (2009). Does the canonical theory of assimilation explain the Roma case? Som eevidence from Central and Eastern Europe. Ethnic and Racial Studies, 32:1387-1405. Raduški, N., (2003) Socio-demographic and ethnic characteristics of the Roma in Serbia. The Sociological Review, 37: 271-284. 
476 Rudic, V., (1978). Population of Toplica, Monograph, Serbian Academy of Science and 477 Technology, Belgrade, Serbia.

478 Sigona,N.,(2005). Locating the“ Gypsy Problem”. The Roma in Italy:Stereotyping, labeling 479 andnomad camps. Journal of Ethnic and Migration Studies, 31:741-756.

480 Sen, A., (2000). Social exclusion: Concept, aplication, and scrutiny. Office of environment 481 and social development Asian development bank.

Sokolovska, V., (2014). On methodology and research sample Social and cultural potential of 483 the Roma ethnic community in Serbia. In The social and cultural potentials of the Roma in 484 Serbia, (prep.), 7-28. Novi Sad: Faculty of Philosophy, Department of Sociology, Center for Sociological Research.

486 Sokolovska, V., Jarić, I., (2014). Educational and economic status of the Roma in Serbia and 487 its regional representation. The Sociological Review, 48: 383-395.

488 SORS., (2014). Basic groups of population. Data by region. Belgrade: Statistical Office of the 489 Republic of Serbia.

490 Stopić, M., Dičić, N., Zorić J., (2009). Protection of environment in the Serbia, Beograd, 491 Dosije studio, European Fund for the Balkans (EU agenda).

492 Sparkes, J., (1999). Schools, education and social exclusion. Centre for analysis of social 493 exclusion. London school of economics.

494 Statistical Office of the Republic of Serbia (http://www.stat.gov.rs).

495 Sundberg, J., (2014). Decolonizing posthumanist geographies. Cultural Geographies.21:33496 47. doi: https://doi.org/10.1177/1474474013486067.

497 Škorić, M., Kišjuhas, A., Škorić, J., (2014), Community network analysis: social capital and 498 the marginalization of the Roma in Serbia. In V. Sokolovska (prep.), The social and cultural 499 potentials of the Roma in Serbia, 79-90. Novi Sad: Faculty of Philosophy, Department of 500 Sociology, Center for Sociological Research. 
501 Todorović, D., (2000). About groups, vocations, customs and religion of the Roma in the 502 work of Tihomir Djorđević. Teme, 24:313-333.

503 Todorović, D., (2011). The Roma in the Balkans and in Serbia. Teme, 35:1137-1174.

504 Turjačanin, V. (2004). Ethnic stereotypes among Bosniak and Serbian youth in Bosnia and 505 Herzegovina. Psychology, 37:357-374.

506 Valjarević, A., Živković, D., Valjarević, D., Stevanović, V., Golijanin., (2014). GIS Analysis 507 of Land Cover Changes on the Territory of the Prokuplje Municipality. The Scientific World 508 Journal,1-8, doi:10.1155/2014/805072.

509 Valjarević, A., Djekić, T., Stevanović, V., Ivanović, R., \& Jandziković, B., (2018). GIS 510 numerical and remote sensing analyses of forest changes in the Toplica region for the period 511 of 1953-2013. Applied Geography, 92, 131-139.

512 Vukanović, TP., (1983). The Roma (Gypsies) in Yugoslavia. Vranje: New Yugoslavia.

513 Wu, S. T., Chen, Y. S. (2016). Examining eco-environmental changes at major recreational 514 sites in Kenting National Park in Taiwan by integrating SPOT satellite images and NDVI. 515 Tourism Management, 57, 23-36. http://dx.doi.org/10.1016/j.tourman. 2016.05.006. 